\title{
Tinjauan Terhadap Penyelesaian Sengketa Pajak Melalui Lembaga Keberatan
}

\author{
Nabitatus Sa'adah \\ Fakultas Hukum, Universitas Diponegoro \\ nabitatus@undip.ac.id
}

\begin{abstract}
This study aims to determine the review of tax dispute resolution through objection agencies. The method used in this study is normative legal research. The results of the study point out that First, the position of the tax objection institution, including one form of administrative effort, is recognized as being in the positive law of Indonesia, specifically to resolve an administrative dispute. Second, the position of the objection institution on the one hand is intended to accelerate the settlement of tax disputes, but on the other hand has a weakness related to the objectivity of the decision considering the breaker is one of the parties that issued the decision. The suggestion of this research is that if the objection institution is seen as very important in its existence, especially in an effort to accelerate the settlement of tax disputes, the institution must be truly able to demonstrate its existence as an institution capable of providing objective dispute resolution. Breakers must uphold moral integrity so that they can produce fair decisions.
\end{abstract}

Keywords: Tax Disputes, Objection Institutions, Legal Settlement

\begin{abstract}
Abstrak
Penelitian ini bertujuan untuk mengetahui tinjauan terhadap penyelesaian sengketa pajak melalui lembaga keberatan. Metode yang digunakan dalam penelitian ini adalah penelitian hukum normatif. Hasil penelitian menujukan bahwa Pertama, Kedudukan lembaga keberatan pajak termasuk salah satu bentuk upaya administrasi diakui keberadaannya dalam hukum positif Indonesia khususnya untuk menyelesaikan suatu sengketa administrasi. Kedua, Kedudukan lembaga keberatan disatu sisi dimaksudkan untuk mempercepat penyelesaian sengketa pajak, tetapi disisi lain mempunyai kelemahan terkait keobyektifan putusan mengingat pemutus adalah salah satu pihak yang mengeluarkan putusan. Saran dari penelitian ini adalah apabila lembaga keberatan dipandang sangat penting keberadaannya khususnya dalam upaya mempercepat penyelesaian sengketa pajak maka lembaga tersebut harus betul-betul mampu menunjukkan eksistensinya sebagai lembaga yang mampu memberi penyelesaian sengketa yang obyektif. Pemutus harus menjunjung tinggi integritas moral sehingga mampu menghasilkan keputusan yang adil.
\end{abstract}

Kata Kunci: Sengketa Pajak, Lembaga Keberatan, Penyelesaian Hukum 


\section{A. Pendahuluan}

Upaya mewujudkan tujuan negara sebagaimana yang tertuang dalam pembukaan Undang-undang Dasar Negara Republik Indonesia tahun 1945 yaitu mewujudkan masyarakat adil dan makmur, maka negara diberi kewenangan untuk memungut pajak dari rakyatnya. Kewenangan negara dalam memungut pajak didasari Pasal 23 A UUD NRI tahun 1945 bahwa " Pajak dan pungutan lain yang bersifat memaksa untuk keperluan negara diatur dengan undang-undang”.

Berkaitan dengan hal tersebut dapat dikatakan bahwa memungut pajak merupakan hak atau kewenangan istimewa yang dimiliki negara. Hak istimewa negara tersebut dikenal dengan exorbitente rechten yaitu hak istimewa negara atau luar biasa yang hanya dimiliki oleh negara yang berdaulat ${ }^{1}$. Rochmat Soemitro menyebut wewenang negara dalam memungut pajak sebagai wewenang atau kedaulatan perpajakan ( Belasting Souvereniteit ) yaitu wewenang mutlak yang ada pada negara untuk mengadakan peraturan-peraturan untuk memungut pajak ${ }^{2}$

Definisi pajak itu sendiri adalah" Iuran rakyat kepada kas negara berdasarkan undang-undang ( yang dapat dipaksakan ) dengan tidak mendapat jasa timbal kontra prestasi ) yang langsung dapat ditunjuk dan digunakan untuk membayar pengeluaran umum ${ }^{3}$. Lebih lanjut dijelaskan bahwa pajak adalah " Perikatan yang timbul karena undang-undang yang mewajibkan seseorang yang memenuhi syarat ( taatbestand ) yang ditentukan dalam undang-undang untuk membayar sejumlah uang tertentu kepada negara yang dapat dipaksakan dengan tidak mendapat imbalan secara langsung dapat ditunjuk yang digunakan untuk membiayai pengeluaran-pengeluaran negara ${ }^{4}$.

Berdasarkan definisi tersebut terlihat bahwa dalam proses pemungutan pajak akan selalu melibatkan dua pihak yakni negara dan rakyat ( wajib pajak ). Negaralah

\footnotetext{
${ }^{1}$ Ida Ayu Putu Widiati, Penagihan Pajak Dengan Surat Paksa Sebagai Sarana Intensifikasi Pajak, Eresco,Bandung, hlm.13

${ }^{2}$ Rochmat Soemitro, Hukum Pajak Internasional Perkembangan Dan Pengaruhnya,Eresco, Bandung, 1977,hlm.8

3 Rochmat Soemitro, Dasar-dasar Hukum Pajak Dan Pajak Pendapatan, Eresco, Bandung, 1990, hlm.5

${ }^{4}$ Rochmat Soemitro, Asas Dan Dasar Perpajakan Jilid 1, Eresco, Bandung, 1990, hlm 51
} 
yang mempunyai hak mutlak untuk memungut pajak sedangkan rakyat mempunyai kewajiban untuk membayar pajak.

Dalam kenyataannya hubungan antara pemerintah ( fiskus ) sebagai pemungut pajak dengan rakyat sebagai (wajib pajak ) terkadang timbul adanya sengketa. Pengertian sengketa pajak itu sendiri disebutkan dalam Pasal 1 ayat ( 5 ) UU No.14 tahun 2002 tentang Pengadilan Pajak yang didefinisikan sebagai berikut :

" Sengketa yang timbul dalam bidang perpajakan antara wajib pajak dengan pejabat yang berwenang sebagai akibat dikeluarkannya keputusan yang dapat diajukan banding atau gugatan kepada Pengadilan Pajak berdasarkan peraturan perundang-undangan perpajakan termasuk gugatan atas pelaksanaan penagihan berdasarkan Undang-undang Penagihan Pajak Dengan Surat Paksa”.

Apabila terjadi sengketa pajak antara wajib pajak dengan fiskus ( Pemerintah), wajib pajak berhak untuk mencari upaya hukum untuk menyelesaikan sengketa. Penyelesaian sengketa pajak dapat diselesaikan melalui upaya keberatan dan penyelesaian sengketa melalui lembaga peradilan.

Penyelesaian sengketa melalui lembaga keberatan merupakan salah satu bentuk penyelesaian sengketa melalui upaya administratif yang dikenal dalam suatu sengketa administrasi. Upaya administratif adalah suatu prosedur yang dapat ditempuh oleh seseorang atau badan hukum perdata yang tidak puas terhadap suatu keputusan tata usaha negara, dimana prosedur tersebut dilakukan di lingkungan Pemerintah sendiri ${ }^{5}$.

Penyelesaian sengketa melalui upaya administratif mengingat pemutus sengketa adalah pihak yang masih masuk lingkungan pemerintah yang notabene pihak yang berperkara maka keobyektifan putusannya sering diragukan, sedangkan suatu penyelesaian sengketa selalu dituntut untuk menghasilkan suatu putusan yang obyektif sehingga mampu memberi perlindungan hukum bagi pihak-pihak yang bersengketa.

${ }^{5}$ SF.Marbun, Peradilan Administrasi Negara Dan Upaya Administratif Di Indonesia, Liberty, Yogyakarta,1997, hlm.66 
Berdasarkan beberapa uraian di atas inilah yang menurut penulis menarik untuk dibuat suatu penulisan ini.

Rumusan Masalah :

1. Bagaimana kedudukan lembaga keberatan pajak dalam sistem peradilan di Indonesia?

2. Bagaimana kedudukan lembaga keberatan pajak apabila dikaitkan dengan perlindungan hukum terhadap wajib pajak ?

\section{B. Pembahasan}

1. Kedudukan Lembaga Keberatan Pajak Dalam Sistem Peradilan di Indonesia

Sebagaimana telah diuraikan sebelumnya bahwa Penyelesaian Sengketa Pajak mengenal penyelesaian sengketa melalui Lembaga Keberatan. Sengketa pajak yang dapat diselesaikan melalui lembaga keberatan adalah sengketa atas Surat Ketetapan Pajak yang berupa Surat Ketetapan Pajak Kurang Bayar (SKPKB), Surat Ketetapan Pajak Kurang Bayar Tambahan (SKPKBT), Surat Ketetapan Pajak Lebih Bayar (SKPLB), Surat Ketetapan Pajak Nihil (SKPN) dan keberatan atas pemotongan atau pemungutan oleh pihak ketiga berdasarkan perundang-undangan perpajakan.Dalam pengajuan upaya keberatan harus disertai dengan surat keberatan.

Surat keberatan adalah surat yang diajukan oleh wajib pajak, yang harus memenuhi syarat-syarat tertentu. Surat keberatan tersebut dapat berupa surat keberatan atas Surat Ketetapan Pajak Kurang Bayar, Surat Ketetapan Pajak Kurang Bayar Tambahan, Surat Ketetapan Pajak Lebih Bayar, Surat Ketetapan Pajak Nihil dan terhadap pemotongan atau pemungutan oleh pihak ketiga berdasarkan ketentuan peraturan perundang-undangan perpajakan. Surat Keberatan tersebut diajukan kepada pejabat yang berwenang mengeluarkan Surat Ketetapan Pajak.

Keberatan diajukan secara tertulis dalam bahasa Indonesia dengan mengemukakan jumlah pajak yang terutang atau jumlah pajak yang dipotong atau dipungut atau jumlah rugi menurut perhitungan wajib pajak dengan disertai alasanalasan yang jelas. 
Penyelesaian sengketa pajak di muka lembaga keberatan, sangatlah berbeda dengan penyelesaian sengketa di muka pengadilan. Surat keberatan diputuskan oleh hakim doleansi ( pejabat pajak yang diberi tugas untuk memutus surat keberatan), tanpa mengadakan sidang seperti yang dilakukan di pengadilan ${ }^{6}$. Pemberian keputusan atas surat keberatan didasarkan atas data yang diajukan oleh wajib pajak dan data yang ada pada fiskus. Pemutusan sengketa dilakukan secara sepihak oleh “hakim” tunggal ( pejabat pajak ) yang notabene merupakan salah satu pihak yang berperkara ${ }^{7}$.

Keputusan atas surat keberatan dapat berupa :

1. Menerima seluruhnya atau sebagian

\section{Menolak}

3. Menambah besarnya jumlah pajak yang terutang.

Apabila surat keberatan diterima seluruhnya maka keputusan tersebut tidak perlu diberi alasan, cukup dinyatakan bahwa keberatan wajib pajak diterima. Tetapi apabila keputusan atas surat keberatan berisi menerima sebagian, menolak atau bahkan menambah besarnya jumlah pajak yang terutang maka keputusan tersebut biasanya disertai dengan alasan-alasan yang mendasarinya.

Jalur penyelesaian sengketa melalui lembaga keberatan dalam hukum administrasi disebut penyelesaian sengketa melalui upaya administratif. Apabila kita lihat dari ciri-ciri di atas maka penyelesaian sengketa pajak melalui lembaga keberatan termasuk kategori penyelesaian melalui peradilan administrasi tidak murni, karena penyelesai dari keberatan pajak itu adalah fiskus, pihak yang notabene merupakan salah satu pihak yang bersengketa. Penyelesaian sengketa seperti ini dalam Hukum Administrasi dikenal juga sebagai upaya administratif.

Dikenalnya penyelesaian sengketa Tata Usaha Negara melalui upaya administratif di Indonesia terlihat dalam Pasal 48 UU No.51 tahun 2009 yang

\footnotetext{
${ }^{6}$ Rochmat Soemitro, Asas Dan Dasar Perpajakan Jilid 2, Eresco, Bandung 1992, hlm.174

${ }^{7}$ Ibid., hlm. 175
} 
merupakan perubahan kedua UU No.5 tahun 1986 tentang Pengadilan Tata Usaha Negara,selanjutnya disebut UU PTUN .

Berdasarkan bunyi Pasal 48 tersebut dan penjelasannya, menurut hukum positif, dalam hal ini UU.No.PTUN, penyelesaian sengketa administrasi dapat dilakukan melalui; Pertama, upaya administratif, menurut penjelasan Pasal 48, yang dimaksud dengan upaya administratif adalah suatu prosedur yang dapat ditempuh oleh seseorang atau badan hukum perdata apabila merasa tidak puas terhadap suatu Keputusan tata Usaha Negara, prosedur tersebut dilakukan dilingkungan pemerintahan sendiri. Dalam upaya administratif penyelesaian sengketa dapat dilakukan melalui prosedur keberatan yaitu penyelesaian sengketa yang dilakukan sendiri oleh Badan atau Pejabat Tata Usaha Negara yang mengeluarkan keputusan dan banding administratif, yaitu penyelesaian sengketa yang dilakukan oleh instansi atasan atau instansi lain yang mengeluarkan keputusan. Kedua, melalui pengadilan.

Penyelesaian sengketa melalui upaya administratif juga diatur juga dalam Undang-undang No.30 tahun 2014 tentang Administrasi Pemerintahan, khususnya Pasal 75. Pasal tersebut menyatakan bahwa apabila masyarakat merasa dirugikan atas keputusan dan /atau tindakan pejabat pemerintah, maka dapat mengajukan upaya administratif kepada pejabat pemerintahan atau atasan pejabat yang menetapkan dan/atau melakukan keputusan/tindakan.

Upaya administratif dalam UU No.30 tahun 2014 disebutkan terdiri atas upaya keberatan dan upaya banding administratif. Upaya keberatan dapat diajukan kepada pejabat yang mengeluarkan keputusan sedangkan banding administratif diajukan kepada atasan yang menetapkan keputusan yang konstitutif.

Berdasarkan uraian di atas apabila dikaitkan dengan lembaga keberatan pajak, pada dasarnya penyelesaian sengketa melalui lembaga keberatan pajak merupakan contoh penyelesaian sengketa melalui upaya administratif, dimana keberadaan keberadaan upaya administratif ini diatur dalam Pasal 48 UU PTUN dan diatur dalam Pasal 75 UU Administrasi Pemerintahan. 
Upaya administrasi yang dikenal dalam penyelesaian sengketa pajak hanyalah penyelesaian sengketa melalui upaya keberatan, hal ini berarti bahwa dalam penyelesaian sengketa pajak tidak mengenal upaya administrasi yang berupa banding administrasi. Apabila wajib pajak tidak puas terhadap putusan dari lembaga keberatan wajib pajak dapat langsung mengajukan banding ke Pengadilan Pajak.

Didalam Pasal 48 ayat ( 2 ) UU PTUN dalam hal suatu sengketa administrasi mengenal penyelesaian sengketa melalui upaya administrasi, jika seluruh upaya administrasi yang ada telah di gunakan maka Pengadilan baru berwenang memutus sengketa Tata Usaha Negara. Pengadilan yang berwenang memutus sengketa tata usaha negara adalah Pengadilan Tinggi Tata Usaha Negara yang bertugas dan berwenang menyelesaikan sengketa di tingkat pertama atas upaya hukum lanjutan dari upaya administrasi tersebut.

Undang-undang Administrasi Pemerintahan memberi pengaturan secara berbeda dalam Pasal 76 ayat (3) menyatakan jika masyarakat tidak menerima keputasan banding oleh atasan maka masyarakat dapat mengajukan upaya gugatan ke Pengadilan. Gugatan ke Pengadilan secara implisit dapat dikatakan pengadilan tingkat pertama PTUN.

Demikian juga penyelesaian sengketa pajak mengingat Pengadilan Pajak hanya ada satu maka Pengadilan Pajak berkedudukan sebagai Pengadilan tingkat pertama dan terakhir dalam memutus sengketa pajak.

Berkaitan dengan beberapa uraian di atas dapat disimpulkan bahwa kedudukan upaya administrasi diakui keberadaannya dalam hukum positif Indonesia khususnya untuk menyelesaikan suatu sengketa administrasi.

\section{Kedudukan Lembaga Keberatan Pajak Dikaitkan dengan Konsep Perlindungan Hukum Terhadap Wajib Pajak}

Seiring dengan perkembangan konsep negara hukum modern kebutuhan akan perlindungan hukum semakin penting. Dalam negara hukum modern, tugas dan fungsi yang diemban administrasi negara berkembang menjadi semakin luas, 
keterlibatan negara turut campur hampir disetiap aspek kehidupan menjadi semakin besar. Agar administrasi negara dapat melaksanakan tugasnya dengan baik, maka kepadanya diberikan kekuasaan dan kebebasan yang semakin besar pula. Salah satu dampak yang timbul sebagai akibat diberikannya kekuasaan dan kebebasan yang besar kepada administrasi negara adalah adanya kecenderungan semakin tingginya penyelewengan atau tindakan yang merugikan rakyat ${ }^{8}$.

Terhadap tindak administrasi negara tersebut dalam kerangka negara hukum, perlindungan terhadap warga negara merupakan suatu hal yang sangat urgen ${ }^{9}$. Perlindungan hukum diberikan dengan meletakkan hak dan kewajiban asasi warga masyarakat dalam keserasian, keseimbangan dan keselarasan antara kepentingan perseorangan dengan kepentingan masyarakat atau kepentingan umum ${ }^{10}$. Salah satu bentuk jaminan perlindungan hukum bagi rakyat atas sikap tindak administrasi negara adalah perlindungan hukum yang bertujuan untuk menyelesaikan sengketa ( perlindungan hukum represif ), yang dapat berbentuk antara lain : disediakannya sarana penyelesaian sengketa yang meliputi institusi atau lembaga yang berwenang untuk menyelesaikan sengketa, diberikannya kemudahan prosedur dalam penyelesaian sengketa, diberikannya kesempatan kepada pencari keadilan untuk mencari keadilan sampai pada tingkat pengadilan yang tertinggi, diberikannya jaminan kepada pencari keadilan untuk dapat menyelesaikan perkaranya secara adil, cepat, tepat, dan biaya ringan, diberikannya jaminan penyelesain sengketa yang seobyektif mungkin, yang bebas dari campur tangan pihak lain dan sebagainya. Hal demikian sesuai dengan asas-asas yang tercantum dalam UU. No. 14 Tahun 1970 jo. UU. No. 48 Tahun 2009 tentang Kekuasaan Kehakiman.

Penyelesaian sengketa melalui upaya administrasi merupakan salah satu bentuk perlindungan hukum terhadap warga negara melalui pengawasan terhadap sikap tindak pejabat administrasi. Sebagaimana di ketahui bahwa tugas negara dalam

\footnotetext{
${ }^{8}$ Parlin M. Mangunsong, Pembatasan Kekuasaan Melalui Hukum Administrasi Negara Makalah, Bandung, 1990, hlm.12

${ }^{9}$ Sjahran Basah, Perlindungan Hukum Terhadap Sikap Tindak Pejabat Administrasi Negara,Alumni, Bandung, 1992 , hlm. 11.

${ }^{10}$ S.F. Marbun, Peradilan Administrasi Negara Dan..., Op.Cit.,hlm.27
} 
pelaksanaan negara hukum modern menjadi semakin komplek. Dalam rangka mencapai hasil yang maksimal dalam menjalankan tugasnya tersebut administrasi negara diberikan suatu kebebasan bertindak untuk menyelesaikan suatu permasalahan yang belum diatur dalam peraturan perundang-undangan dan membutuhkan suatu penyelesaian yang cepat, kebebasan bertindak ini disebut pouvoir discretionnaire atau freies ermessen. Diberikannya kewenangan yang luas kepada pejabat administrasi negara ini disisi lain memungkinkan pejabat administrasi negara melakukan tindakan yang merugikan subyek hukum peradata. Lord Action mengatakan Power tends to corrupt and absolute power tends to corrupt absolutly ${ }^{11}$. Tindakan administrasi negara yang dapat merugikan subyek hukum perdata antara lain dapat berupa; tindakan yang melanggar ( onrechtmatige overheids daad ), penyalah gunaan wewenang ( deternement de pouvoir) dan kesewenang-wenangan ( abus de droit ) . Dalam rangka pemberian perlindungan hukum kepada masyarakat atas tindakan administrasi negara yang merugikan tersebut maka perlu ada pengawasan.Pengawasan terhadap administrasi negara dapat berupa pengawasan ekstern dan pengawasan intern. Pengawasan ekstern adalah pengawasan yang secara organisatoris/ stuctural berada diluar pemerintah (dalam arti eksekutif) sedangkan pengawasan intern adalah pengawasan yang dilakukan oleh suatu badan yang secara organisatoris / structural masih termasuk lingkungan pemerintah sendiri ${ }^{12}$. Salah satu bentuk pengawasan intern adalah upaya administrasi.

Penyelesaian sengketa melalui upaya administratif dimaksudkan untuk memudahkan pencari keadilan memperoleh keadilan dan memperoleh perlindungan hukum,baik bagi administrasi sendiri maupun bagi warga ${ }^{13}$. Prinsip penyelesaian sengketa melalui upaya administrasi adalah mengutamakan musyawarah sehingga meminimalkan penyelesaian sengketa melalui peradilan. Demikian juga dalam penyelesaian sengketa pajak. Salah satu dasar pertimbangan semula, diberikannya penyelesaian sengketa pajak melalui lembaga keberatan adalah untuk mempercepat

11 Sjachran Basah, Perlindungan Hukum ...., Op.Cit,hlm. 6

12 Diana Halim, Arti, Cara Dan Fungsi Pengawasan, ( Dalam buku Dimensi-dimensi Hukum Administrasi Negara), UII Pers, Yogyakarta, 2002, hlm.263

${ }^{13}$ S.F. Marbun, Peradilan Administrasi Negara Dan..., Op.Cit., hlm. 107 
penyelesaian sengketa pajak, sehingga lebih cepat memberi kepastian hukum bagi kedua pihak baik wajib pajak maupun fiskus itu sendiri ${ }^{14}$.

Sebagai suatu lembaga yang berwenang menyelesaikan sengketa, kedudukan lembaga upaya administratif ini mempunyai beberapa kelemahan, kelemahan penyelesaian sengketa melalui upaya ini antara lain; ketiadaannya hukum acara serta kelemahan yang berkaitan dengan netralitas atau keobyektifan lembaga tersebut dalam memberi suatu penyelesaian sengketa, mengingat kedudukan lembaga tersebut yang berada dalam lingkungan pemerintahan sendiri..

Upaya mengatasi kelemahan tersebut menurut SF.Marbun perlu adanya perumusan hukum acara sebagai standar dalam pemeriksaan upaya administrasi dan untuk menjawab persoalan yang berkaitan dengan keobyektifan lembaga pemutus dapat ditempuh beberapa alternatif, atara lain dengan cara pertama, menempatkan badan ( majelis ) tersebut diluar instansi kedua, dinas yang bersangkutan atau menempatkan majelis tetap merupakan bagian dari instansi yang bersangkutan dengan komposisi keanggotaan dari majelis haruslah pejabat senior yang memiliki tanggung jawab dan moral yang tinggi ${ }^{15}$.

Meskipun sudah ditawarkan beberapa alternatif untuk mengatasi kelemahan upaya administrasi khususnya yang berkaitan dengan keobyektifan lembaga pemutus hal tersebut masih menimbulkan keraguan mengingat meskipun ada penempatan majelis di luar instansi tetapi instansi tersebut masih merupakan kepanjangan tangan dari pemerintah maka keobyektifanya masih patut diragukan.

Keberadaan upaya administrasi dalam penyelesaian sengketa pajak menurut penulis di satu sisi memang dapat mempercepat penyelesaikan sengketa mengingat penyelesaian tersebut adalah penyelesaian di luar jalur litigasi. Sebagaimana diketahui penyelesaian melalui jalur litigasi mempunyai kelemahan lamanya proses penyelesaian sengketa. Proses penyelesaian sengketa pajak yang lama akan

\footnotetext{
${ }^{14}$ Hussein Kartasasmita, Reformasi UU Perpajakan,Jakarta, 1998, hlm.102

${ }^{15}$ SF.Marbun, Op.Cit., hlm.112
} 
menganggu proses penerimaan negara, mengingat pajak ada sumber andalan penerimaan negara

Penyelesaian sengketa pajak melalui upaya administrasi di sisi yang lain menimbulkan keraguan terkait dengan keobyektifan putusan . Penyelesaian sengketa pajak oleh lembaga yang juga mempunyai otoritas untuk mengeluarkan Surat Ketetapan Pajak, keobyektifannya wajar apabila dianggap kurang dapat terjamin, dan dianggap lebih banyak dipengaruhi kepentingan institusi yang orientasinya lebih terfokus pada upaya peningkatan penerimaan pajak. Pemutus dihadapkan pada kondisi yang dilematis karena disatu sisi harus memberi keputusan ketetapan pajak, namun disisi lain harus mengeluarkan putusan keberatan. Kekhawatiran terhadap keobyektifan lembaga ini sangat beralasan juga manakala dikaitkan dengan asas “ Tidak seorangpun dapat menjadi hakim yang baik untuk dirinya sendiri (nemo judex indoneus in propia causa ) “ 16 .

Apabila lembaga keberatan ini dipandang perlu untuk tetap dipertahankan sebagai lembaga penyelesai sengketa pajak maka lembaga keberatan pajak tersebut harus betul-betul mampu keluar dari kepentingan institusi yang menaunginya.Pemutus harus betul-betul menjungjung tinggi integritas moral sehingga mampu membangun kepercayaan rakyat melalui keputusan yang adil.

\section{Simpulan:}

1. Kedudukan lembaga keberatan pajak termasuk salah satu bentuk upaya administrasi diakui keberadaannya dalam hukum positif Indonesia khususnya untuk menyelesaikan suatu sengketa administrasi.

2. Kedudukan lembaga keberatan disatu sisi dimaksudkan untuk mempercepat penyelesaian sengketa pajak, tetapi disisi lain mempunyai kelemahan terkait keobyektifan putusan mengingat pemutus adalah salah satu pihak yang mengeluarkan putusan

Saran

\footnotetext{
${ }^{16}$ Sudikno Mertokusumo, Hukum Acara Perdata Indonesia, Liberty, Yogyakarta, hlm.18-19
} 
Apabila lembaga keberatan dipandang sangat penting keberadaannya khususnya dalam upaya mempercepat penyelesaian sengketa pajak maka lembaga tersebut harus betul-betul mampu menunjukkan eksistensinya sebagai lembaga yang mampu memberi penyelesaian sengketa yang obyektif. Pemutus harus menjunjung tinggi integritas moral sehingga mampu menghasilkan keputusan yang adil.

\section{Daftar Pustaka}

Diana Halim, Arti, Cara Dan Fungsi Pengawasan, ( Dalam buku Dimensi-dimensi Hukum Administrasi Negara), UII Pers, Yogyakarta, 2002

Ida Ayu Putu Widiati, Penagihan Pajak Dengan Surat Paksa Sebagai Sarana Intensifikasi Pajak, Eresco,Bandung

Parlin M. Mangunsong, Pembatasan Kekuasaan Melalui Hukum Administrasi Negara Makalah, Bandung, 1990

Rochmat Soemitro, Asas Dan Dasar Perpajakan Jilid 1, Eresco, Bandung, 1990 Asas Dan Dasar Perpajakan Jilid 2, Eresco, Bandung 1992, Dasar-dasar Hukum Pajak Dan Pajak Pendapatan, Eresco, Bandung, 1990 , Hukum Pajak Internasional Perkembangan Dan Pengaruhnya,Eresco, Bandung

SF.Marbun, Peradilan Administrasi Negara Dan Upaya Administratif Di Indonesia, Liberty, Yogyakarta,1997

Sjahran Basah, Perlindungan Hukum Terhadap Sikap Tindak Pejabat Administrasi Negara,Alumni, Bandung, 1992

Sudikno Mertokusumo, Hukum Acara Perdata Indonesia, Liberty, Yogyakarta. 